\title{
Photogrammetry and Laser Scanning for Reconstruction and Restoration of Historical Buildings
}

\author{
Svetlana Golovina ${ }^{1,}{ }^{*}$ and Svetlana Kanyukova ${ }^{2}$ \\ ${ }^{1}$ Saint Petersburg State University of Architecture and Civil Engineering, Vtoraya Krasnoarmeiskaya \\ ul. 4. St. Petersburg, 190005, Russia \\ ${ }^{2}$ Peter the Great Saint-Petersburg Polytechnic University, Politekhnicheskaya, 29, Saint-Petersburg, \\ 195251, Russia
}

\begin{abstract}
Scientific and fundamental metrology concerns the development of new measurement methods. Technology development evaluates in the emergence of new devices, methods and techniques, allowing to obtain spatial and geometric information about constructions with greater accuracy and less labour- and time-consumption. Applied metrology concerns the application of measurement science to their use in society. Such information is of great importance, since the use of these data can provide, for example, a complete view of the construction project documentation accuracy or will allow for further structure and facility monitoring, deviations of structures from the design project, sediment and overall construction state. Another important application is the imprinting objects, in particular listed buildings, in order to preserve their appearance, meaning the use of this data in the restoration or rehabilitation facilities. During the subsequent processing information can be transformed into other forms of fixation like drawings and three-dimensional model. Metrology has thrived at the interface between science and manufacturing. Particularly, Laser scanning and Photogrammetry methods found their wide application in solving practical tasks in architecture and building construction. These are the most common methods of obtaining this information. The article presents the description of both methods and discusses their advantages and disadvantages, as well as aspects, which determine the use of a particular method in different situations.
\end{abstract}

\section{Introduction}

The problem of listed buildings and structures fixing methods improvement, in our opinion, is always actual. The traditional form of fixing as an album with photos saves just an object appearance information. It can't give exact information about geometrical properties of object as shooting is conducted on not metric and not calibrated cameras. There are also other known forms of fixing - drawings. They provide geometry, but don't represent the exact appearance of object. Besides, creation of drawings is labour-consuming and expensive. Emergence of new geodetic devices (system of laser scanning) and digital photogrammetry methods development can provide brand new forms of fixing [1]. 
Technologies of creating three-dimensional models of historical buildings and various construction objects have been developing for more than 20 years in Russia and abroad. Commonly model is created based on results of the land laser scanning (LLS). Many scientists take this approach as a most reasonable one because of the received result accuracy.

Use of laser scanning technologies in 3D design during product creation or modernization allows to create uniform design-technology model, provides effective enterprise designers, technologists and other specialists interaction, and in general considerably reduces terms and increases quality of technological product preparation. 3D design technologies allow to increase work productivity due to a possibility of implementing expeditious changes at any design stage, simultaneous work on model of several people, simplification of design decisions development by means of standardization [2]

A large number of scientific articles confirms efficiency of modern laser scanning methods use, this technology in the few years will become very convenient and technological standard of fixing and documenting of historical objects shapes [3]. Most often LLS is used in restoration projects such as Alexander Nevsky's church in Chelyabinsk [4] or Alexander Nevsky's temple in Novosibirsk [3].

Photogrammetry is generally used for obtaining drawings of buildings facades. This method of inspection has proved itself well in construction branch.

As two various technologies used for the solution of similar tasksPhotogrammetry and LLS were compared many times.

However, techniques allowing to receive $3 \mathrm{D}$ models directly from photos using only mathematical algorithms of processing which are carried out on personal computers appeared recently.

Combination of laser scanning data and Photogrammetry is interesting for foreign researchers also, such as Alshawabkeh Y., Haala N., Nuttens T., De Maeyer P., De Wulf A., Goossens R., Stal C., Baltsavias E.P., Ravanel L., Curtaz M., [5-23], who apply these methods in archaeological works and projects of historically important architectural objects archiving. Besides, researchers in other fields of science, such as a mine surveying [24] and mechanical engineering are engaged in studying of this problem [25].

Comparison of the automated models creation methods on the basis of laser scanning and a Photogrammetry data will allow to define strong and weak points of both methods which is necessary for their effective sharing [26-34].

\section{Theoretical or experimental methods}

The work purpose is comparison of model creation results in program complexes derived from laser scanning and from method of a photogrammetry and consideration of these models possible application for various purposes.

Along with advantages three-dimensional laser systems have also shortcomings: difficulties in irregular shaped objects interpretation; complexity of objects vectorization by "a cloud of points"; slow work with big sized files; it is necessary to work with fragments of an object to increase speed of materials processing. Complex usage of photogrammetric and three-dimensional laser scanning methods opens new opportunities for technological development of architectural constructions measurements and measurement drawings creation [26].

Beside the improvement of a scanning data in particular (a cloud of points method), it is possible to improve a method efficiency by a combination of it with the existing methods. Many modern scanners have the built-in camera which usually doesn't allow to receive the facsimile suitable for photogrammetric processing. But at the same time the modern digital cameras which are available on market for low price are allow to receive high-quality 
photographic materials. Joint digital facsimiles and a cloud of points processing can also increase data process efficiency considerably as facsimiles are much closer to person's natural object perception than a cloud of points, and also allow to obtain object information in places, which are hard for scanning, - with the presence of obstacles and sharp geometrical changes [27].

The calibrated digital camera, the application for processing of materials of tacheometric survey, a program complex for calculation of elements of orientation and transformation of pictures are necessary for a technology of three-dimensional building model creation with a photogrammetric method.

Listed stages are necessary to create a model by a photogrammetry method. The first stage is field works, including photogrammetric shooting of an object. Next step is a field materials processing which includes affixment results processing and picture correction of result, and also analyse and transformation of pictures in a program complex. The last stage is creation of a three-dimensional model and imposing of textures.

The land laser scanning system consists of LLS (land laser scanner) and the field personal computer with the specialized software. There are laser scanning systems with a built-in control system or support of the wi-fi technology for contact with the personal computer. NLS consists of the laser range finder adapted for work with high frequency and a laser beam development block. The servodrive - a type of the mechanical drive with sensors of provisions, speeds, efforts, etc. acts as the development block in LLS, and the control unit of the drive which is automatically supporting necessary parameters on the sensor and in the device itself, accordingly, depending on the set external value, and also a polygonal mirror or a prism. The servodrive rejects a beam at the set size in the horizontal plane, at the same time the whole upper part of the scanner which is called a head turns. Vertical motion is carried out due to rotation or swing of a mirror. During the scanning the direction of distribution of a laser beam and distance to object points is fixed.

The cloud of points which is a number of object's points with three-dimensional coordinates, from which there was a reflection of a laser signal, is a result of land laser scanning. The cloud of the points covering an object surface forms his spatial dot model.

Processing of the results happens in the program complexes allowing to transform the received cloud of points to other types of fixing: drawings, dot three-dimensional models, orthophotomap, raster development.

\section{Experimental section}

For model creation methods application the building of Pavlovsky leib-gvardii polka barracks has been chosen - the listed building of the 19th century. It represents a sample of typical Russian classicism and now it is protected by the state. The building is located at the Marsovo pole sq., 1, the central part of a facade facing Millionnaya st. has been chosen. 


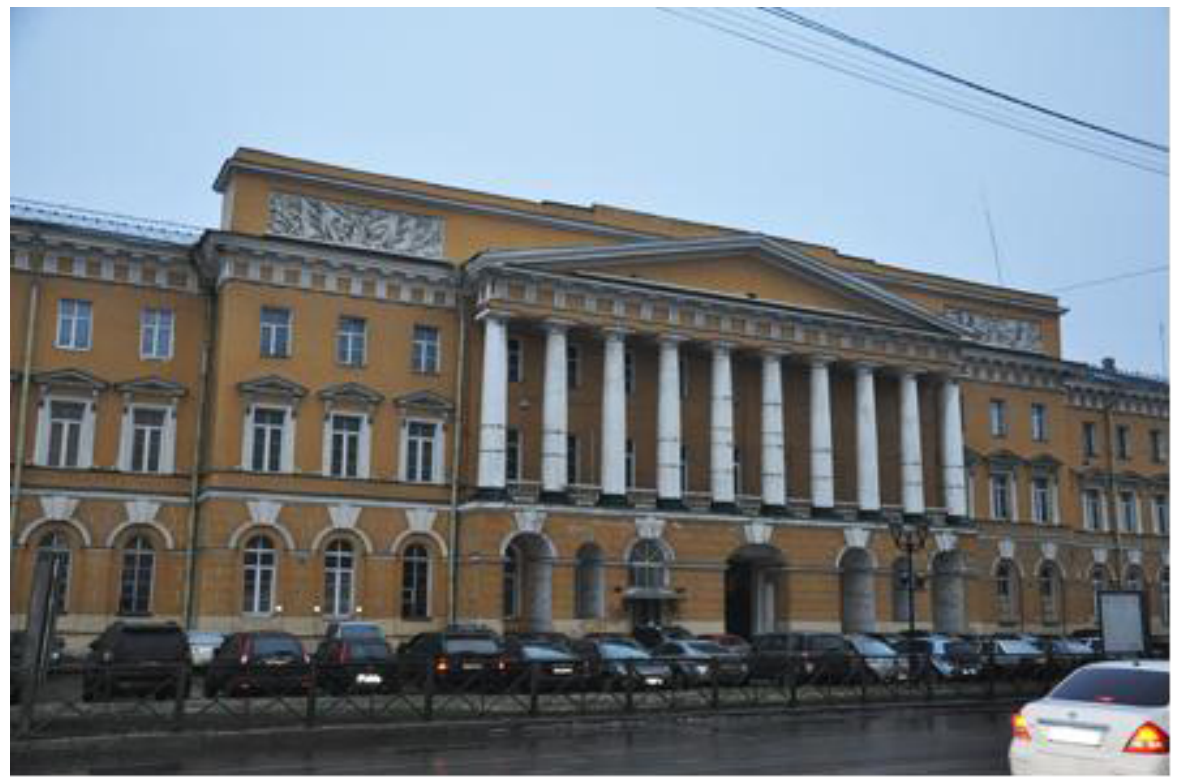

Fig. 1. Building of Pavlovsky leib-gvardii polka barracks

\section{Results and discussion}

Laser scanning has been conducted by means of the Leica Scanstation 2 scanner with an 6 $\mathrm{mm}$ accuracy of position in space definition , $4 \mathrm{~mm}$ distances to object accuracy and the 2 $\mathrm{mm}$ accuracy of a surface modeling. While shooting in the automatic mode of polygonal model creation was used, therefore total integrity of model was a little reduced. It has been made for research process acceleration. Usually when scanning architectural objects with manual modeling, which allows to receive more high-precision model. The figure 1 allows to allocate following shortcomings of the automatic mode of a polygonal grid creation:

1) the noise in the lower part which has appeared because of the parked cars and the passing pedestrians;

2) noise in windows - a problem of transparent surfaces scanning;

3) lack of data on shadowed parts of a facade (not visible from points of standing of the scanner) - places behind columns, the lower part of a pediment.

The model of a facade (fig. 2, 3, 4) is constructed of the cloud of points received when scanning by means of the Trimble RealWorks program complex. 


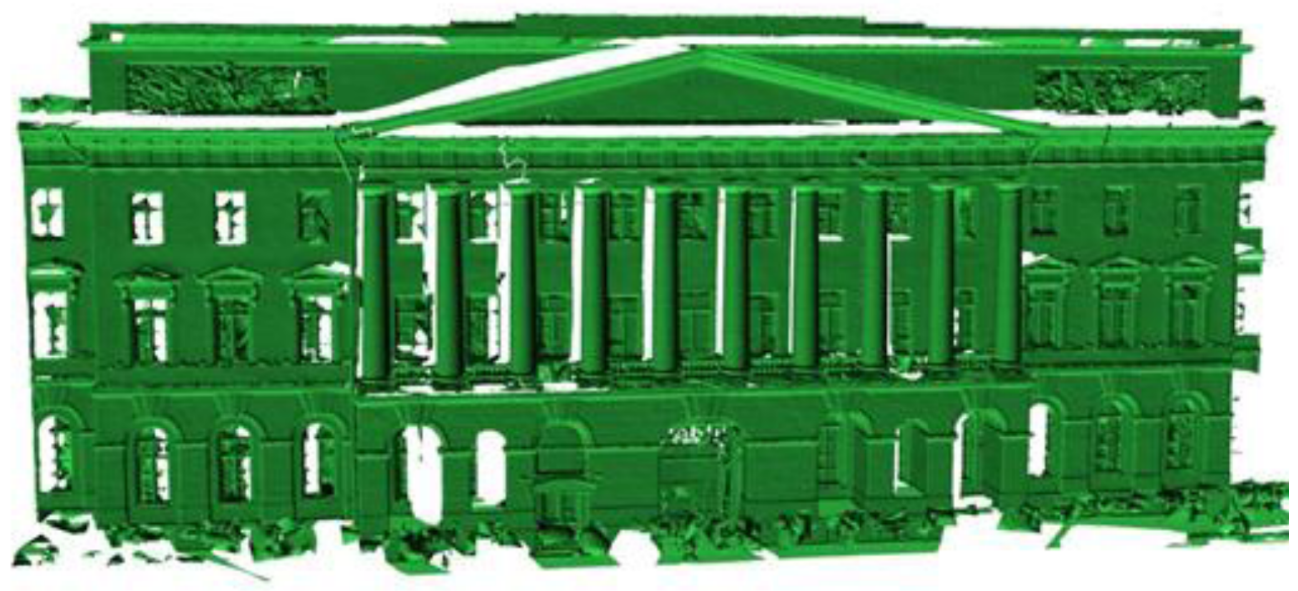

Fig. 2. Building facade model in the Trimble RealWorks program

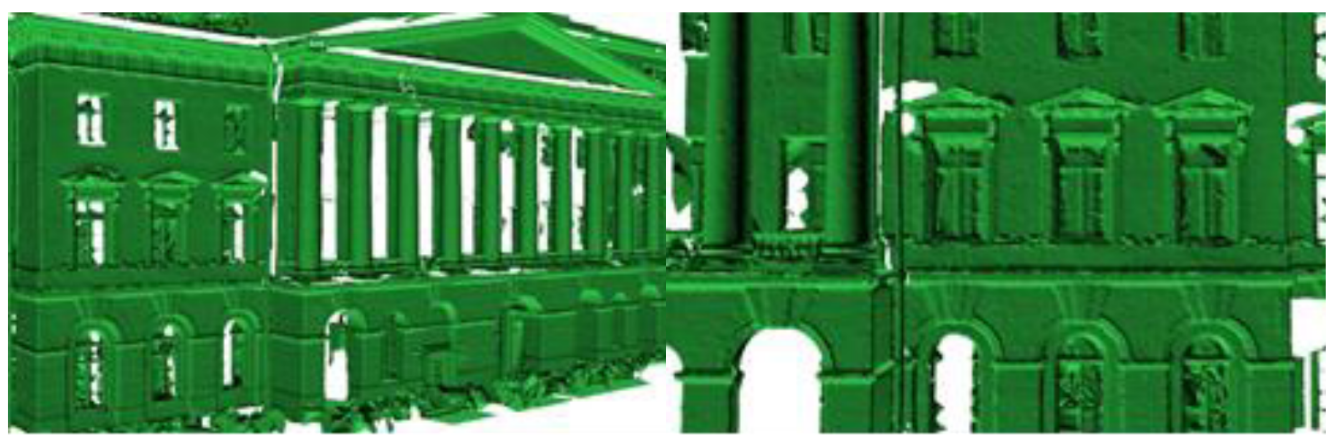

Fig. 3. The left-side view on a facade

Fig. 4. The fragment of façade from the right

The figures show that integrity of object and elements of a facade is preserved, even fine architectural details on model, which sizes can be received with high precision are distinguishable. The labour consisted of 3 man hours for field works and 3 man hours for data processing.

Photogrammetric shooting of a facade by means of the NIKON D90 camera has been executed also. 17 pictures with the resolution of $4288 \times 2848$ have been taken so that the pictures, next to each other according to an arrangement, overlapped each other not less than for $40 \%$. The model of object has been executed in the Agisoft Photoscan program (fig. 5, 6, 7). 


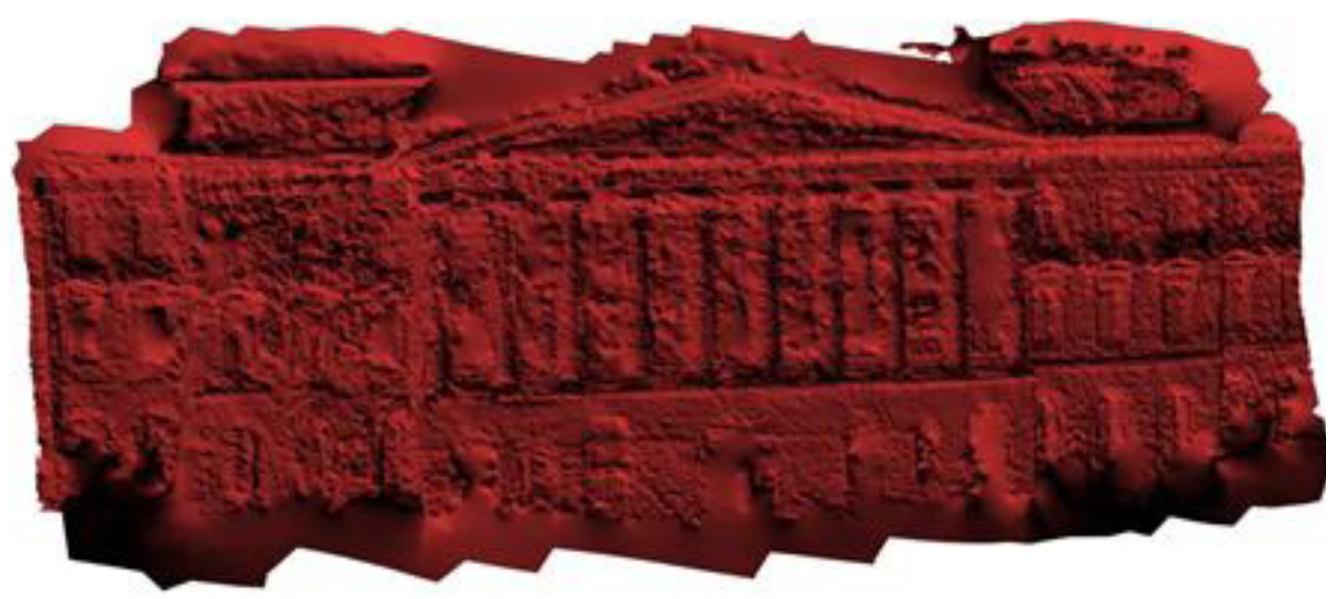

Fig. 5. The building facade Model in the Agisoft Photoscan program

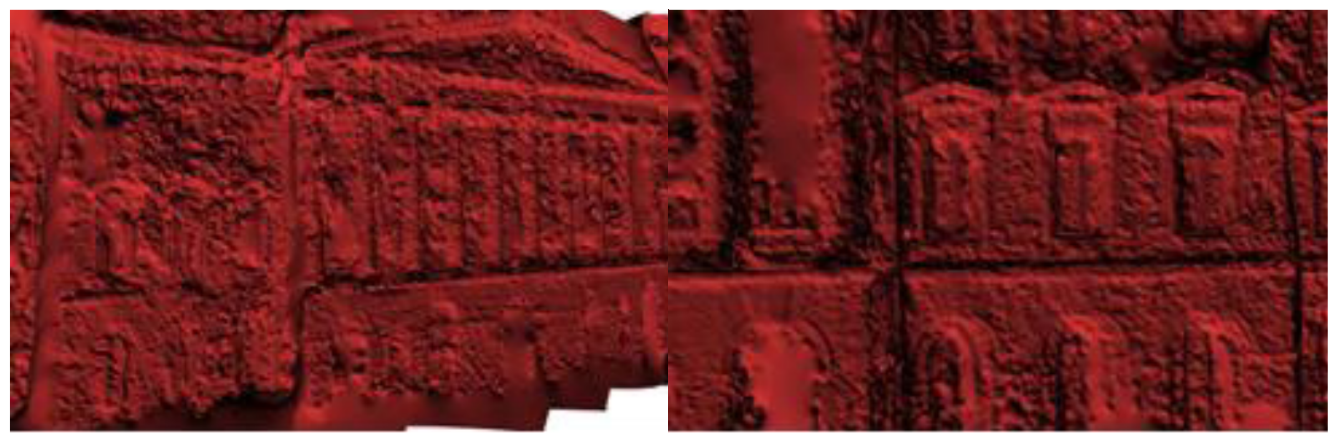

Fig. 6. Left-side view on a facade

Fig. 7. The fragment of façade from the right

The figures show that the received model has a number of deficiencies, only the general form of object and the main architectural elements are preserved, and smaller sites of a facade and elements of the second place (a window behind columns and interiors of apertures) in general remain indiscernible.

Later the overlapping of models on each other has been carried out (fig. 8, 9, 10). It is visible on drawings that the model according to photos is much worse. 


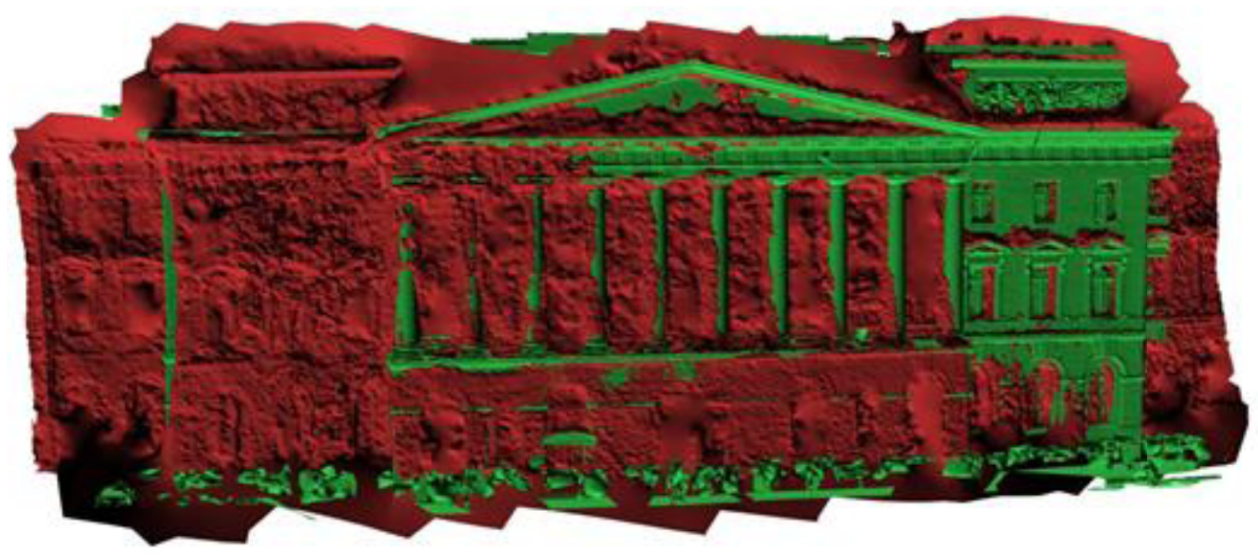

Fig. 8. Result of models overlapping

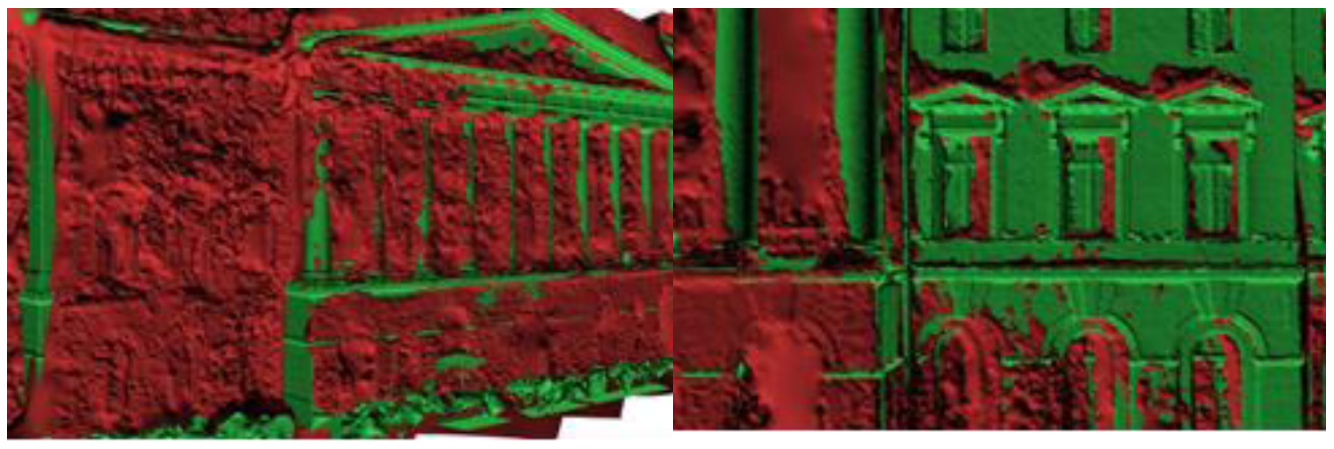

Fig. 9. Left-side view on a facade

Fig. 10. The fragment of façade from the right

Total labour consisted 0,5 man hours for field works and 2 man hours for data processing.

\section{Conclusions}

The model received using a photogrammetric method can be used for purposes when high precision is not necessary, for example for the fact-finding purposes or for saving information about the appearance of object. The main advantage of this method is the possibility of receiving the textured model which is most precisely transferring visual characteristics of object (color, invoice). The model received by scanning has much higher precision and degree of specification - this method can be used for control of geometrical parameters compliance of again constructed objects and project documentation on these objects or their adjustments, and also for monitoring of these parameters. Besides, this way can be used for objects restoration, the lost documentation recovery and creation of drawings. At the same time texturing of such model is quite labour-intensive process as it is necessary to carry out overlapping of photos for this purpose which leads to the merge of photogrammetry and laser scanning methods. 


\section{References}

1. S.V. Tyurin, S.G. Tikhonov, Magazine of Civil Engineering, 7, 25-30 (2010)

2. I.K. Kiyamov, R.Kh. Mingazov, A.F. Muzafarov, R.A. Ibragimov, A.A. Sibgatullin, Exposition Oil \& Gas magazine, 7(32), 41-43 (2013)

3. A.V. Radzyukevich, M.A. Chernova, V.A. Seredovich, A.V. Ivanov, Interexpo Geo Siberia, 3, 115-126 (2012)

4. I.G. Shchegolev, A.A. Demin, A.D. Olenkov D.S. Popov, PNRPU Construction and Architecture Bulletin, 1, 95-98 (2011)

5. M.G. Sinkova, Razrabotka i issledovaniye fotogrammetricheskikh tekhnologiy obmerov arkhitekturnykh sooruzheniy s ispolzovaniyem lazernykh trekhmernykh skanerov (2004)

6. V.I. Galakhov, Razrabotka metodiki sozdaniya vektornykh modeley obyektov po rezultatam nazemnogo lazernogo skanirovaniya i tsifrovoy fotosyemki (2012)

7. Information on http://www.racurs.ru/www_download/articles/Camaras_digitale s_rus.pdf

8. E.P. Baltsavias, ISPRS Journal of Photogrammetry and Remote Sensing, 54, 83-94 (1999)

9. Y. Alshawabkeh, N. Haala, CIPA 2005 XX International Symposium (2005)

10. Y. Alshawabkeh N. Haala, D. Fritsch, IAPRS, XXXVI, (2006)

11. Information on http://citeseerx.ist.psu.edu/viewdoc/download?doi=10.1.1.42.6581\& rep=rep1\&type $=$ pdf

12. Information on http://www.fig.net/pub/fig2011/papers/ts06e/ts06e_nuttens demaeyer_et_al_5267.pdf

13. Information on: https://www.fig.net/pub/athens/papers/ts26/ts26_4_guarnieri_et_al.pdf

14. Information on: http://www.permanetalpinespace.eu/archive/pdf/WP6_1_tls_tp.pdf

15. Information on: http://www.divaportal.org/smash/get/diva2\%3A120447/FULLTEXT01.pdf

16. Information on: http://kth.divaportal.org/smash/get/diva2:139761/FULLTEXT01.pdf

17. Information on: URL: http://etd.fcla.edu/UF/UFE0000526/drake_d.pdf

18. Information on: http://cipa.icomos.org/fileadmin/template/doc/PRAGUE/079.pdf

19. Information on: http://www.isprs.org/proceedings/XXXVI/3W52/final_papers/Gonzalez_Aguilera_2007.pdf

20. S. Al-Kheder, Y. Al-shawabkeh, N. Haala, Journal of Archaeological Science, 36(2), 537-546 (2009)

21. L. Svatovskaya, A. Sychova, M. Sychov, V. Okrepilov, MATEC Web of Conferences, 53, Article Number 01023 (2016)

22. K. Lambers, H. Eisenbeiss, M. Sauerbier, D. Kupferschmidt, T. Gaisecker, S. Sotoodeh, T. Hanusch, Journal of Archaeological Science, 34(10), 1702-1712 (2007)

23. A. Pesci, M. Fabris, D. Conforti, F. Loddo, P. Baldi, M. Anzidel, Journal of Volcanology and Geothermal Research, 162(3-4), 123-138 (2007)

24. M. Sturzenegger, D. Stead, Engineering Geology, 106(3-4), 163-182 (2009)

25. H. Gonzalez-Jorge, B. Riveiro, P. Arias, J. Armesto, Measurement, 45(3), 354$363(2012)$

26. A.S. Korchukov, A.V. Leonov, Technology and organization of building production, 1 (2),49-51 (2013) (rus) 
27. A.V. Leonov, Yu.M. Baturin, I.A. Petropavlovskaya, Voprosy istorii estestvoznaniia i tekhniki (VIET), 3, 156-170 (2013)

28. V.L. Kvint, V.V Okrepilov, Herald of the Russian Academy of Sciences, 84 (3), 188-200 (2014)

29. V.V Okrepilov, V.N. Krutikov, G.I. El'kin, Measurement Techniques, 57 (2),109$116(2014)$

30. V.V Okrepilov, A.Yu. Smirnov, Measurement Techniques, 56(1), 54-60 (2013)

31. V.V Okrepilov, Studies on Russian Economic Development, 24(1), 35-42 (2013)

32. V.V Okrepilov, Standarty i Kachestvo, 10, 52-55 (2005)

33. V.V Okrepilov, Ivanova, G. Standarty i Kachestvo, 12, 62-68. (2004)

34. V.V Okrepilov, Standarty i Kachestvo, 3, 94-96. (2003) 